\title{
BURN OUT
}

Dieter Helm is fellow in economics, New College, and professor of economic policy, University of Oxford. His previous books include The Carbon Crunch: How We're Getting Climate Change Wrong - and How to Fix It (2012, 2015) and Natural Capital: Valuing the Planet (2015), both published by Yale University Press. In 2017 Professor Helm carried out the Cost of Energy Review for the UK government.

'The book's grand scope and its provocative line should provoke considerable and fruitful debate.'

Peter Christoff, Australian Book Review 


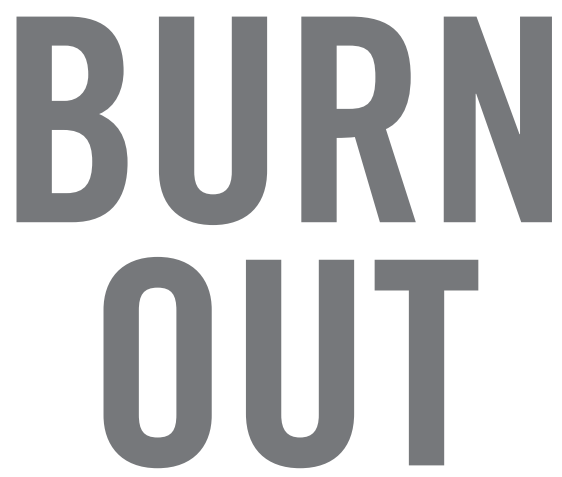

THE ENDGAME FOR FOSSIL FUELS

\author{
DIETER HELM
}

UPDATED EDITION 
Copyright (C) 2017 Dieter Helm

First published in paperback 2018

All rights reserved. This book may not be reproduced in whole or in part, in any form (beyond that copying permitted by Sections 107 and 108 of the U.S. Copyright Law and except by reviewers for the public press) without written permission from the publishers.

For information about this and other Yale University Press publications, please contact: U.S. Office: sales.press@yale.edu yalebooks.com

Europe Office: sales@yaleup.co.uk yalebooks.co.uk

Typeset in Minion Pro by IDSUK (DataConnection) Ltd

Printed in Great Britain by Hobbs the Printers, Totton, Hampshire

Library of Congress Cataloging-in-Publication Data

Names: Helm, Dieter, author.

Title: Burn out : the endgame for fossil fuels / Dieter Helm.

Description: New Haven : Yale University Press, [2017] | Includes bibliographical references and index.

Identifiers: LCCN 2016043323 | ISBN 9780300225624 (c1 : alk. paper)

Subjects: LCSH: Energy industries. | Energy development-Environmental aspects. | Energy consumption-Environmental aspects. | Renewable energy sources. | Fossil fuels-Environmental aspects.

Classification: LCC HD9502.A2 H4549 2017 | DDC 333.8/2-dc23

LC record available at https://lccn.loc.gov/2016043323

A catalogue record for this book is available from the British Library.

IBSN 978-0-300-23448-0 (pbk)

10987654321 
To Sue, Oliver and Laura - as always 
